\title{
Mechanism of crust formation on a soil in central Iran
}

\author{
Mostafa K. Eghbal, Mohammad A. Hajabbasi and Hossein T. Golsefidi \\ College of Agriculture, Isfahan University of Technology, Isfahan, Iran*
}

Received 21 July 1995. Accepted in revised form 5 December 1995

Key words: Beta vulgaris, crust formation, infiltration, micromorphology, seedling emergence

\begin{abstract}
Crust formation on soils around Isfahan reduces infiltration and seedling emergence in cultivated lands. Mechanism of crust formation on local soils was investigated under field condition. Soil and crust samples from a field under furrow irrigation were taken for physical, chemical and micromorphological analysis. Seedling emergence of sugar beets (Beta vulgaris) reduced by $50 \%$ due to crust forming after the first irrigation. Rise of water table, increase of exchangeable sodium percentage to 6.4 , and higher silt content resulted in higher susceptibility of soil to crust formation. Crust forming inside furrows was thicker and usually consisted of 3 layers as compared to a thinner crust formed on beds with only 2 layers. Layers found in crusts of Lavark soil generally had less sand and more silt and fine clay compared to the overall Ap horizon. Silt and fine clay in the middle M2 layer of crust forming on furrows were increased from 51.6 and 5.6 to 59.8 and 21.1 percent respectively. Percolation of finer particles through and inside the pores created layers that were denser and less porous. Chemical dispersion of particles together with physical deterioration of surface structure by long period of mechanized agriculture in the area are probably the main reasons for crust formation.
\end{abstract}

\section{Introduction}

Crust formation is a major problem on many soils of cultivated land in arid and semi-arid parts of central Iran. Surface crusts are usually thin ( $<2 \mathrm{~mm}$ to $3 \mathrm{~mm}$ ) and have greater density, finer pores, and lower saturated hydraulic conductivity than the underlying soils (Shainberg and Singer, 1985).

Arshad and Mermut (1988) reported three kinds of crusts: i) disruptional crust, formed due to breakdown of soil aggregates under rain-drops in silty soils; ii) sedimentational crust, formed on soil from surface runoff; iii) laminar crust, forming in clayey soils with high exchangeable $\mathrm{Na}$ and $\mathrm{Mg}$. Shainberge and Singer (1985) recognized two kinds of depositional crusts: one made of flocculated particles and much faster permeability, and the second made of dispersed clay and silt particles. The former formed in a soil with low exchangeable sodium percentage (ESP $<5$ ) and the latter formed in a soil with higher ESP and lower electrical conductivity $\left(\mathrm{EC}<0.3 \mathrm{dS} \mathrm{m}^{-1}\right)$. Agassi et al.

\footnotetext{
* FAX No: + 318912254
}

(1981) reported chemical dispersion reduces sharply in soils with low ESP $(\approx 5)$ when electrolyte concentration increases to $5 \mathrm{meq} \mathrm{L}^{-1}$.

The micromorphology of soil crusts has been studied with the aid of optical techniques (Arshad and Mermut, 1988; Evans and Buol, 1968; Le Souder et al., 1990). Scanning electron microscopy (SEM) has also been used to examine undisturbed soil crust sections (Chen et al., 1980; Moore and Singer, 1990; Onofiok and Singer, 1984). Soil micromorphology together with the aid of physical and chemical analysis of soil crust can be used to better understand the mechanism of crust formation. The objective of this study was to examine factors influencing crust formation on a soil in field condition araund Isfahan.

\section{Materials and methods}

The study area is located in central Iran within Isfahan Province (Fig.1). Lavark soil (fine-loamy, mixed, thermic Typic Haplargids) was chosen for this study 
Table 1. Physical and morphological properties of Lavark soil

\begin{tabular}{|c|c|c|c|c|c|c|c|c|}
\hline \multirow[t]{2}{*}{ Horizon } & \multirow{2}{*}{$\frac{\text { Depth }}{\text { (cm) }}$} & \multirow[t]{2}{*}{ Texture } & Sand & Silt & Clay & \multirow{2}{*}{$\begin{array}{l}\text { Bulk } \\
\text { Density } \\
\left(\mathrm{Mg} \mathrm{m}^{-3}\right)\end{array}$} & \multirow[t]{2}{*}{ Structure $^{a}$} & \multirow[t]{2}{*}{ Pores $^{a}$} \\
\hline & & & & $(\%)$ & & & & \\
\hline Ap & $0-20$ & sil & 28 & 52 & 20 & 1.73 & Massive & If dis.i \\
\hline Bw & $20-50$ & $\mathrm{cl}$ & 31 & 36 & 33 & 1.74 & lc sbk & $\operatorname{lm}$ con. $\mathrm{i}$ \\
\hline $\mathrm{Bt}$ & $50-100$ & $\mathrm{cl}$ & 24 & 31 & 45 & 1.5 & $2 \mathrm{c} s b k$ & $2 \mathrm{~m}$ and $\mathrm{c}$ con $\mathrm{t}$ \\
\hline Btb & $100-150$ & sicl & 18 & 41 & 41 & 1.5 & $2 \mathrm{~m} \mathrm{sbk}$ & $2 \mathrm{c}$ con $\mathrm{t}$ \\
\hline
\end{tabular}

${ }^{a}$ Structure and pores are described using USDA-SCS abbreviations.

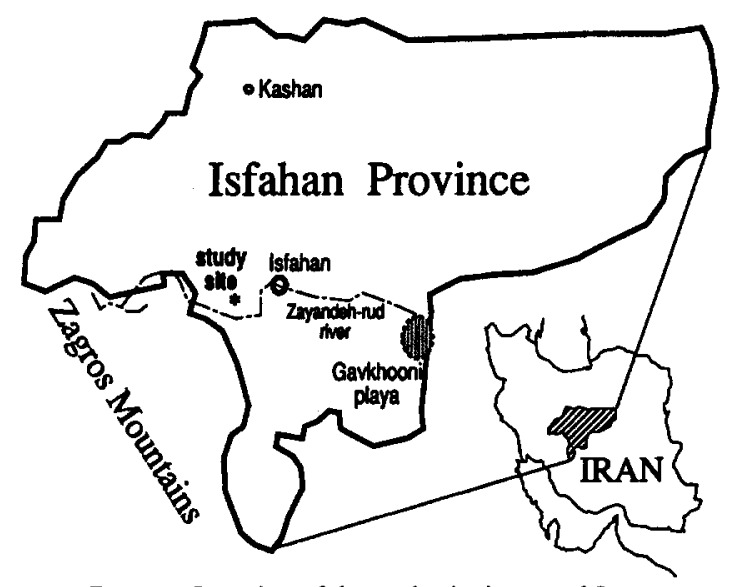

Figure 1. Location of the study site in central Iran.

because it was known to have serious infiltration problems, presumed to be associated with surface crusting. The soil is formed in alluvial sediments of Zayandehrud river. A 2.3 ha plot, planted with sugar beets (Beta vulgaris) and irrigated using furrows, was chosen for this study.

Morphological properties of soil horizons were described from a profile excavated to a depth of 150 $\mathrm{cm}$ and soil samples were taken for physical and chemical analyses. Soil particle size distribution was determined using the pipet method (Gee and Bauder, 1986). Bulk densities were measured using the clod method (Blake and Hartge, 1986). Thin layers of crusts were also separated and analyzed for particle size distribution. Electrical conductivity, $\mathrm{pH}$, cation exchange capacity (CEC) and soluble and extractable cations were determined (Soil Conservation Service, 1984). Exchangeable sodium percentage (ESP) was calculated from exchangeable cation data. Carbonate and bicarbonate in saturation extract was measured by acid neutralization (US Salinity Laboratory, 1954).

Double ring method was used to measure infiltration before and after irrigation on furrows and beds.
Infiltration measurements were replicated at three sites within the field. To measure infiltration with minimum disturbance soil surface was covered with plastic and was slowly removed as soon as water was applied. Seedlings were counted after thinning in $10 \mathrm{~m}$ interval on beds to compare emergence in areas with crust and with no crust. Crust samples were collected from different parts of the field after each irrigation for micromorphological observation.

Undisturbed crust samples were impregnated with Petropoxy-15 resin (Palous Petro Products, Palous, WA) for thin section preparation. Warm Petropoxy was applied directly to a warm crust sample to aid resin absorption. Due to the abundance of discontinuous pores in the crust layers, impregnation under vacuum was not effective. Many successive resin applications and grinding were necessary to achieve a fully impregnated face. The thin sections were observed and photographed with an Olympus petrographic microscope.

\section{Results and discussion}

\section{Physical and morphological properties}

Lavark soil has had a history of crust formation on the surface but in recent years the problem has been more serious. Physical deterioration of surface soil is shown by massive structure, higher bulk density and less observable porosity (Table 1). The texture of surface soil has higher silt content as compared with lower horizons which has made it more susceptible to physical deterioration and crust formation. Crust usually forms after the first irrigation. The Bw horizon also has high bulk density and weak structure probably due to compaction with heavy machinery. The area under study has been under mechanized agriculture in the past 30 years. 
Table 2. Infiltration rate in the field before and after crusting on beds and on furrows

\begin{tabular}{llll}
\hline \multirow{2}{*}{$\begin{array}{l}\text { Time } \\
(\mathrm{min})\end{array}$} & $\mathrm{Bl}^{z}$ & $\mathrm{AF}^{z}$ & $\mathrm{AB}^{z}$ \\
\cline { 2 - 4 }$\left(\mathrm{cm} \mathrm{h}^{-1}\right)^{y}$ \\
\hline 2 & $51.9 \mathrm{a}$ & $40.5 \mathrm{~b}$ & $50.4 \mathrm{a}$ \\
4 & $42.3 \mathrm{a}$ & $34.9 \mathrm{~b}$ & $42.0 \mathrm{a}$ \\
6 & $36.5 \mathrm{a}$ & $31.4 \mathrm{a}$ & $36.9 \mathrm{a}$ \\
11 & $23.0 \mathrm{a}$ & $20.4 \mathrm{a}$ & $23.6 \mathrm{a}$ \\
16 & $17.4 \mathrm{a}$ & $16.0 \mathrm{a}$ & $18.2 \mathrm{a}$ \\
21 & $14.3 \mathrm{a}$ & $13.5 \mathrm{a}$ & $15.2 \mathrm{a}$ \\
31 & $10.2 \mathrm{a}$ & $9.8 \mathrm{a}$ & $11.0 \mathrm{a}$ \\
41 & $8.1 \mathrm{a}$ & $7.9 \mathrm{a}$ & $8.8 \mathrm{a}$ \\
51 & $6.7 \mathrm{a}$ & $6.7 \mathrm{a}$ & $7.4 \mathrm{a}$ \\
81 & $4.4 \mathrm{a}$ & $4.4 \mathrm{a}$ & $4.8 \mathrm{a}$ \\
111 & $3.2 \mathrm{a}$ & $3.3 \mathrm{a}$ & $3.6 \mathrm{a}$ \\
\hline
\end{tabular}

${ }^{z} \mathrm{Bl}=$ before irrigation, $\mathrm{AF}=\mathrm{after}$ irrigation on furrows, $\mathrm{AB}=\mathrm{after}$ irrigation on beds.

${ }^{y}$ Values followed by the same letter on each row are not significantly different at $p=0.05$ by Duncan's test.

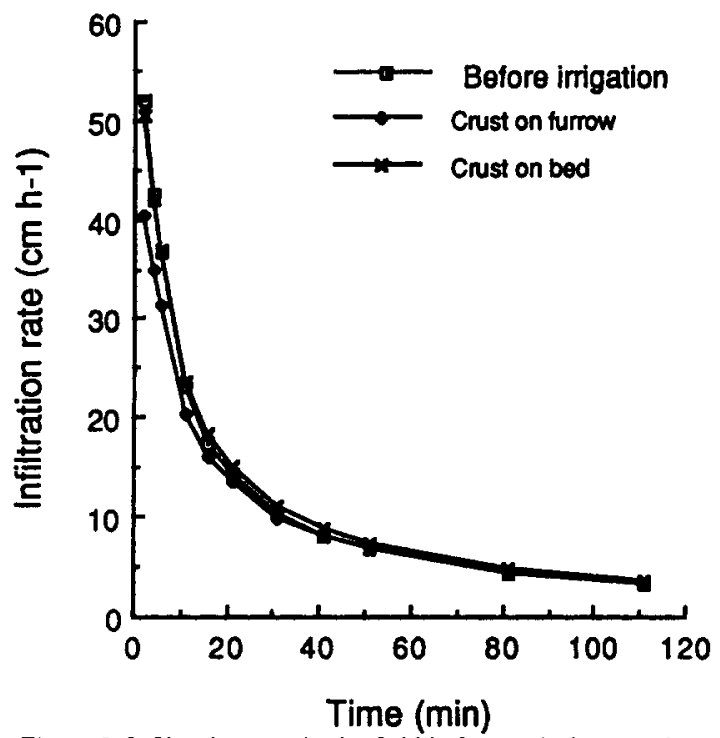

Figure 2. Infiltration rate in the field before and after crusting.

Although crust inside furrows may have reduced the initial infiltration to some degree, but overall infiltration was similar for soils with and without crust (Fig. 2). The infiltration rate attempts to be relatively high at first, but soil surface condition could affect the magnitude and slope of infiltration at different stages (Hillel, 1982). Statistical analysis for infiltration measurements shows that infiltration rates were only higher for the first two measurements (time) on non-crusted

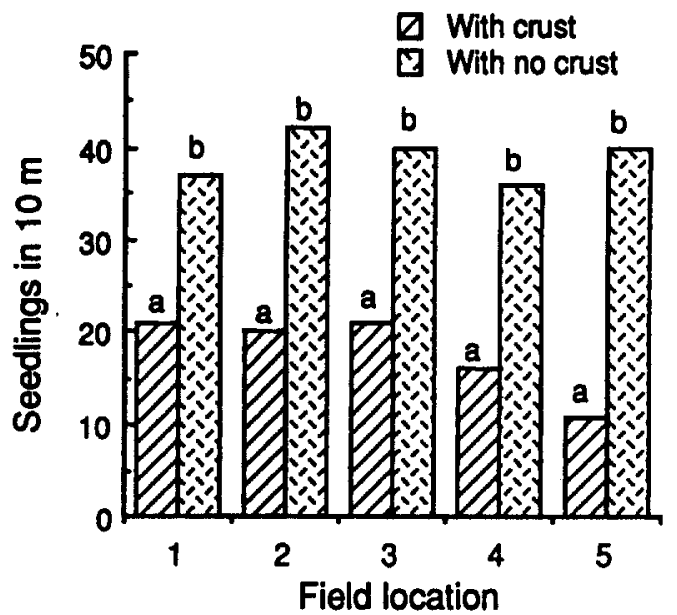

Figure 3. Influence of crusting on seedling emergence. Values with the same letter are not significantly different at $p=0.05$ by Duncan's test.

soils and crusted beds as compared to furrows with thicker crust (Table 2). The surface crust can act as a hydraulic barrier impeding infiltration in soils with no crust. Similarity of infiltration rates in crusted and non-crusted soils (especially after the first stage) in this study may indicate that pores created by cultivation are temporary and clods are quickly destroyed to seal the soil after the first irrigation.

Local farmers prefer furrow irrigation for sugar beets because they get better seedling emergence. However, if top of the furrows are covered by water seedling emergence decreases drastically. Figure 3 shows the number of seedlings after thinning in areas with and without crust on the surface. On average, there is about $50 \%$ reduction in seedling emergence due to crust formation. This percent would have been higher if seedling were counted before thinning.

\section{Crust morphology}

Observation of crusts showed that they consist of layers with different texture and morphology. To further investigate the mechanism of crust formation, particle size distribution of each recognizable layer was determined (Table 3 ). Crusts forming in furrows normally showed three layers while those on beds usually had two layers. The layers are named M1, M2, M3 from bottom to the top after Le Souder et al. (1990).

Layers found in crusts of Lavark soil generally have less sand and more silt and clay compared to the overall Ap horizon. Except in M3 layer found on crust inside furrows (M3-f), all layers have higher fine clay content than coarse clay. 


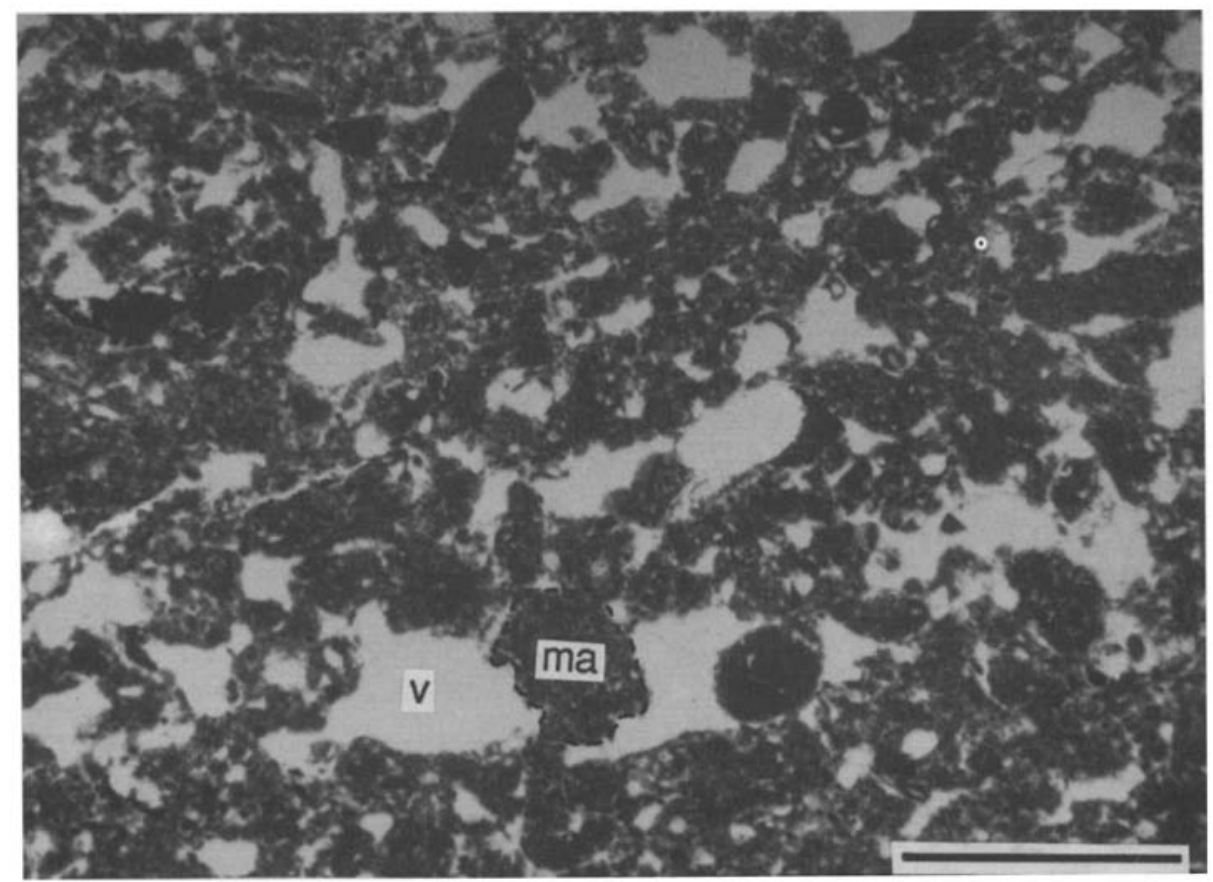

Figure 4. Thin section micrograph of Ml layer from a crust formed on beds. The bar is $1 \mathrm{~mm}(\mathrm{v}=$ voids, $\mathrm{ma}=$ micraaggregates $)$.

Table 3. Particle size distribution of crust layers ${ }^{a}$

\begin{tabular}{lccccc}
\hline $\begin{array}{l}\text { Crust } \\
\text { layers }\end{array}$ & Sand & Silt & Clay & $\begin{array}{l}\text { Fine } \\
\text { clay }\end{array}$ & $\begin{array}{l}\text { Coarse } \\
\text { clay }\end{array}$ \\
\cline { 2 - 6 } & \multicolumn{5}{c}{$(\%)$} \\
\hline $\begin{array}{l}\text { Furrows } \\
\text { M3-f }\end{array}$ & 24.7 & 54.3 & 21 & 5.1 & 15.9 \\
M2 & 17.5 & 59.8 & 22.7 & 21.1 & 1.6 \\
M1 & 24.7 & 55.7 & 23.5 & 19 & 4.5 \\
Beds & & & & & \\
M3-b & & & & & \\
M1 & 18.8 & 53.9 & 27.2 & 22.6 & 4.6 \\
& 24.5 & 54.5 & 24 & 19.3 & 4.7 \\
Overall Ap horizon & 28.5 & 51.6 & 19.8 & 5.6 & 14.2 \\
\hline
\end{tabular}

${ }^{a}$ Values for each size fraction is an average of 3 samples taken from different parts of the field.

M1 layer, both in furrows and on beds, show an increase in fine clay and silt and a decrease in sand content, as compared to ovcrall Ap horizon. The increase in total clay and silt are probably due to percolation of these finer particles inside and through the pores into lower layers (Onofiok and Singer, 1984; Shainberge and Singer, 1985). Figure 4 shows the micromorphology of M1 layer from a crust formed on beds. The pores in this layer are usually discontin- uous orthovughs (Brewer, 1964). Within the s-matrix, very little skeleton grain is present. The thickness of M1 layer varics and its morphology gradually becomes similar to Ap horizon.

The structure of the Ap horizon is massive, but microaggregates were observed in the thin sections specially in M1 layers. Presence of flocculated particles in crust layers indicate that crust is depositional (Arshad and Mermut, 1988; Shainberge and Singer, 


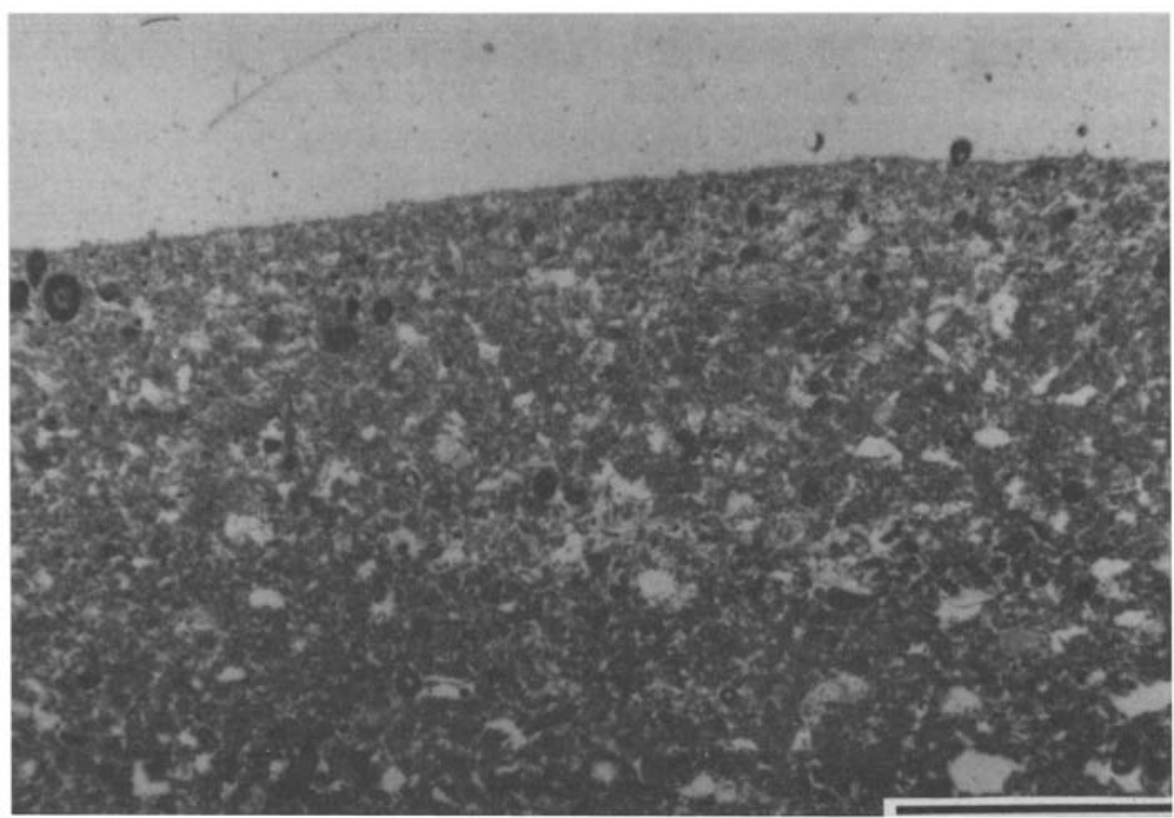

Figure 5. Thin section micrograph of $\mathrm{M} 2$ layer from a crust formed inside furrows. The bar is $1 \mathrm{~mm}$.

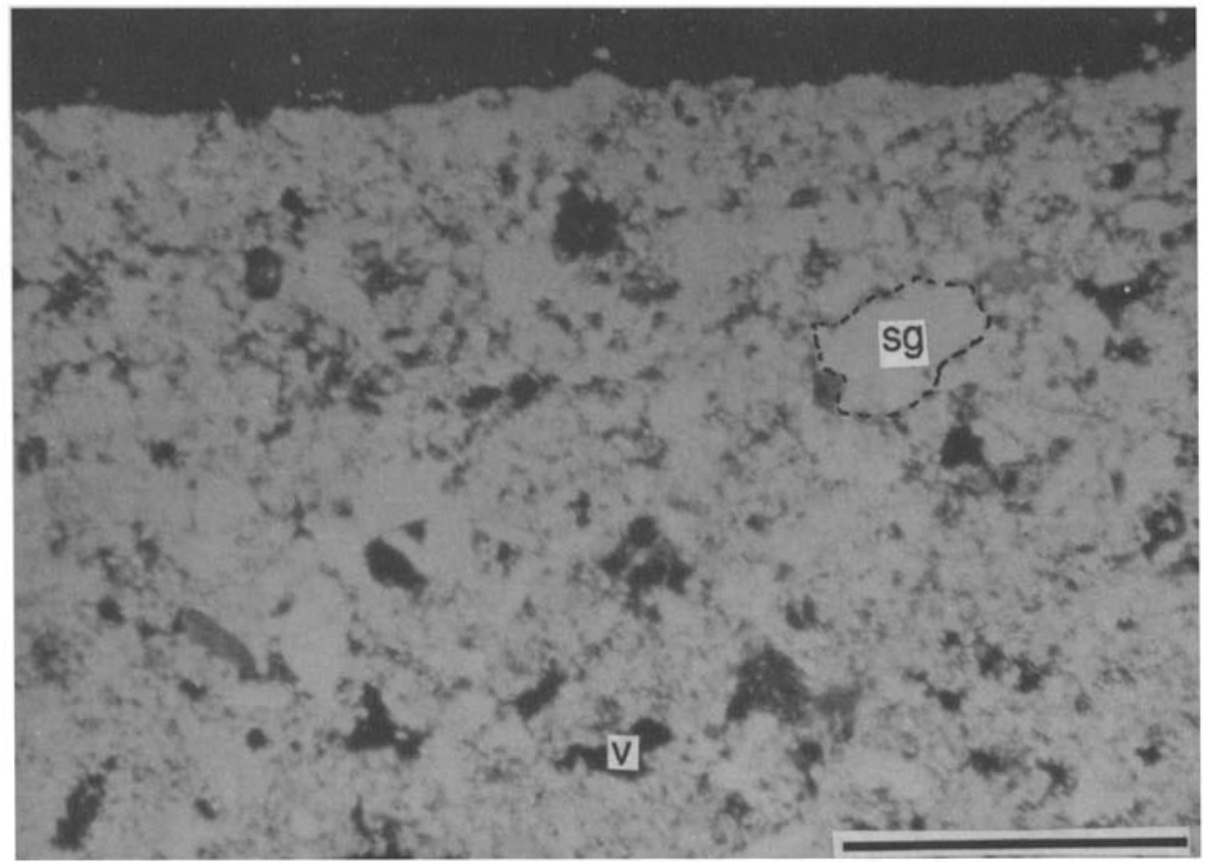

Figure 6. Thin section micrograph of M3-f layer from a crust formed inside furrows. The bar is $500 \mu(\mathrm{v}=$ voids, $\mathrm{sg}=\mathrm{skeleton}$ grains).

1985). Arshad and Mermut (1988) suggested sedimentational (depositional) crusts form from surface runoff, as compared with laminar and disruptional crusts, which form on soils with high clay and exchangeable
$\mathrm{Na}$, and from breakdown of aggregates under raindrop respectively.

The M2 is a dense layer which was only observed inside furrows. In addition to increase in fine clay and silt contents, the M2 layer shows a decrease in sand 


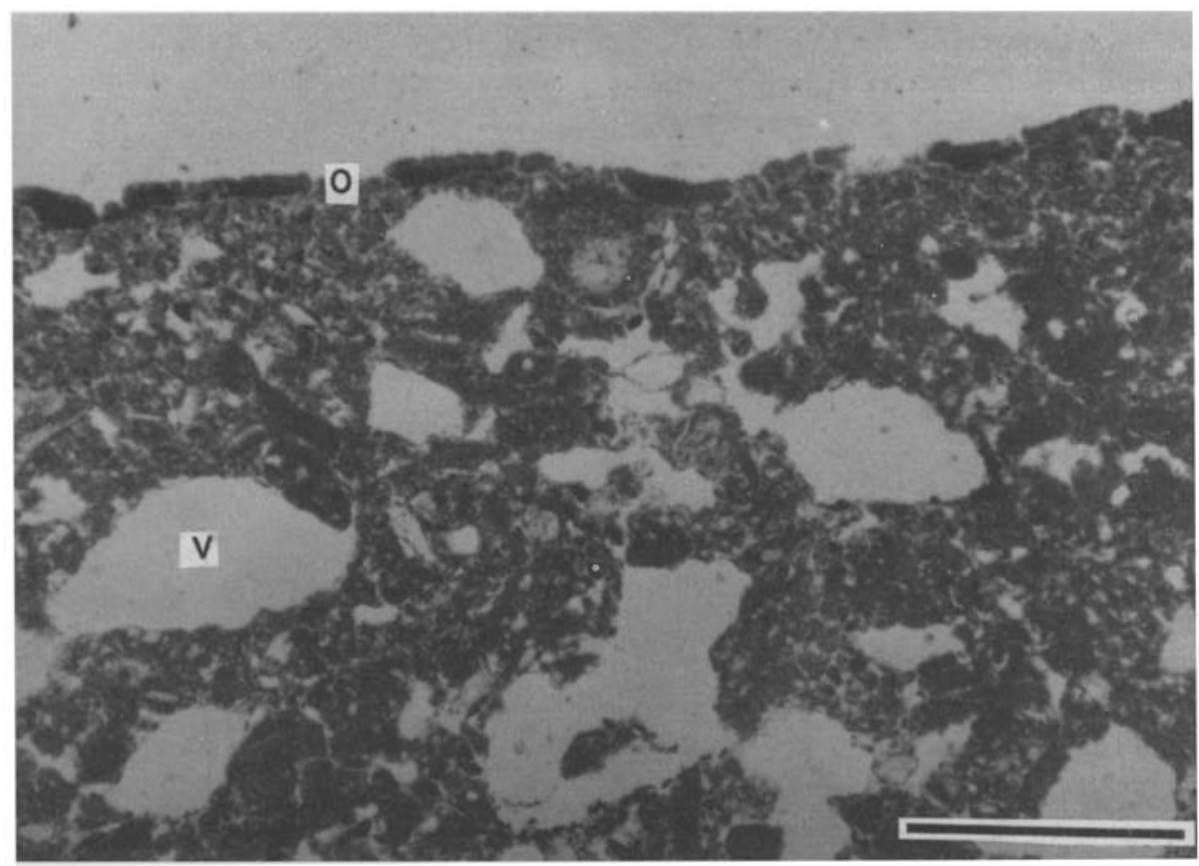

Figure 7. Thin section micrograph of M3-b layer from a crust formed on beds. The bar is $1 \mathrm{~mm}$ ( $0=$ organic layer, $\mathrm{v}=$ voids).

content (Table 3). The percolation of finer particles has apparently occurred more in this layer as compared to M1 layer. Figure 5 illustrates the micromorphology of an M2 layer from a crust inside furrows. The thickness of M2 layer varies between 2 to $5 \mathrm{~mm}$.

M3 is a thin layer (about $1 \mathrm{~mm}$ ) with different morphology on beds compared to furrows. The M3 layer inside furrows (M3-f) has higher skeleton grain and lower porosity (Fig. 6). The particle size distribution of this layer (Table 3) shows that it is similar to the overall Ap horizon. Movement of water and more turbulence inside furrows is probably the reason for higher sand and lower fine clay contents in this top layer as compared to bottom layers of crusts. The M3 layer on beds (M3-b) has 6\% (absolute) less sand as compared to M3-f (Table 3) and it usually has a much thinner organic rich part on the top of it (Fig. 7). The lower sand content and finer plasma indicates that M3-b is formed by slow deposition of fine particles on the top. Crust on beds show no M2 layer and M3-b usually lies on the top of the M1 layer.

\section{Chemical properties}

Chemical properties of soil can also influence the formation of crusts (Shainberge and Singer, 1985). Selected chemical properties of Lavark soil is shown in Table
Table 4. Chemical analysis af Lavark soil

\begin{tabular}{lllll}
\hline $\begin{array}{l}\text { Depth } \\
(\mathrm{cm})\end{array}$ & $\begin{array}{l}\mathrm{pH} \\
\text { sat. ext. }\end{array}$ & $\begin{array}{l}\mathrm{EC} \\
\left(\mathrm{dS} \mathrm{m} \mathrm{m}^{-1}\right)\end{array}$ & SAR & ESP \\
\hline $0-20$ & 7.8 & 3.7 & 5.6 & 6.4 \\
$20-50$ & 7.8 & 1.4 & 4.5 & 5.1 \\
$50-100$ & 7.7 & 1.4 & 3.9 & 4.3 \\
$100-150$ & 7.8 & 1.3 & 3.3 & 3.5 \\
Irrig. water & 7.8 & 1.14 & - & - \\
\hline
\end{tabular}

4. Soil samples and irrigation water had $\mathrm{pH}$ around 7.8. The EC increases toward the surface, due to a higher water table $(\approx 300 \mathrm{~cm})$ in recent years. The rise of the water table has probably been caused by rice cultivation in surrounding areas. Sodium adsorption ratio (SAR) and exchangeable sodium percentage (ESP) also follow the same increasing trend toward the surface. The higher exchangeable sodium may be a factor in crust formation by causing dispersion at the time of irrigation. However, higher EC in the surface horizon could prevent chemical dispersion significantly (Agassi et al., 1981). The increase of finer particles in crust layers (Table 3 ) suggests that chemical dispersion could partly be responsible for reduced infiltration. Although dispersion of finer particles may be a factor in crust formation in Lavark soil, but as described in pre- 
vious section, some stable microaggregates are present in crust layers. This shows that chemical condition of the soil does not allow total dispersion of clays and that higher EC and presence of divalent cations help the formation of some microaggregates.

\section{Summary and conclusions}

Formation of crust on Lavark soil after the first irrigation reduced seedling emergence by 50 percent. The surface horizon has higher silt content which has made it more susceptible to physical deterioration and crust formation. In fields with furrow irrigation, two kinds of crusts are formed. The crust inside furrows is thicker and has 3 layers as compared with the crust on beds with only 2 layers. Particle size distribution of the bottom M1 layer in both locations show that fine clay and silt content increase and sand content decreases. The middle M2 layer, which is found in crusts formed inside furrows, is more compacted, less porous, and has the highest silt content. Increase of clay and silt fraction in M1 and M2 layers is due to percolation of these finer particles through the pores. The top M3 layer on beds has more clay and less sand as compared to M3 layer on crusts inside furrows. Although ESP is relatively high (6.4), but higher EC $\left(3.7 \mathrm{dS} \mathrm{m}^{-1}\right)$ should help prevent dispersion and thus crust formation. Formation of microaggregates in M1 layer may support this idea.

Micromorphological observation and particle size distribution in crust layers, however, suggest that dispersion of clay and silt particles and their percolation through the pores are also responsible for the reduced infiltration. Overall, it may be concluded that higher exchangeable sodium together with physical deterioration of surface structure due to a long period of mechanized cultivation on the silty Lavark soil has created a suitable condition for crust formation. This study was conducted only on one type of soil. Further studies are needed to have a better understanding of crust formation for other type of soils and also to clarify the effect of exchangeable sodium on crust micromorphology.

\section{Acknowledgements}

The authors would like to thank Isfahan University of Technology, Research Division, for financially supporting this study. We also thank the staff of Azar Refractory Co in Isfahan for preparing some of the micrographs from thin sections. We are grateful to $\mathrm{Dr}$ Majid Afyuni for his review of the manuscript.

\section{References}

Agassi M, Shainberge I and Morin J 1981 Effect of electrolyte concentration and soil sodicity on infiltration rate and crust formation. Soil Sci. Soc. Am. J. 45, 848-851.

Arshad M A and Mermut A R 1988 Micromorphological and phsicochemical characteristics of soil crust type in northern Alberta, Canada. Soil Sci. Soc. Am. J. 52, 724-729.

Blake G R and Hartge K H 1986 Bulk density. In Methods of Soil Analysis. Part 1. 2nd ed. Ed. A Klute. pp 363-375. Agronomy Monograph 9. ASA and SSSA, Madison, WI, USA.

Brewer R 1976 Fabric and Mineral Analysis of Soil. 2nd print Robert E Krieger Publ. Co., New York, USA.

Evans D D and Buol S W 1968 Micromorphological study of soil crust. Soil Sci. Soc. Am. Proc. 32, 19-23.

Gee G W and Bauder J W 1986 Particle size analysis. In Methods of Soil Analysis. Part 1, 2nd ed. Ed. A Klute. pp 383-411. Agronomy Monograph 9. ASA and SSSA, Madison, WI, USA.

Hillel D 1982 Introduction to Soil Physics. Academic Press, New York, USA.

Le Souder C, Le Bissonnais Y, Robert M and Bresson L M 1990 Prevention of crust formation with a mineral conditioner. In Soil Micromorphology a basic and applied Science. Ed. L A Douglas. pp 81-87. Elsevier, Amsterdam, the Netherlands.

Moore D C and Singer M J 1990 Crust formation effect on soil erosion processes. Soil Sci. Soc. Am. J. 54, 1117-1123.

Onofiok O and Singer M J 1984 Scanning electron microscope studies of surface crusts formed by simulated rainfall. Soil Sci. Soc. Am. J. 48, 1137-1143.

Shainberge I and Singer M J 1985 Effect of electrolytic concentration on the hydraulic properties of depositional crust. Soil Sci. Soc. Am. J. 49, 1260-1263.

Soil Conservation Service 1984 Soil survey laboratory methods and procedures for collecting soil samples. USDA-SCS Soil Surv Invest. Rep. no. 1. U.S. Gov. Print. Office, Washington, DC, USA.

US Salinity Laboratory 1954 Diagnosis and improvement of saline and alkali soils. USDA Handb. 60. U.S. Gov. Print. Office, Washington, DC, USA.

Section editor: $B$ E Clothier 